\title{
Acid-base chemistry and proton conductivity of CsHSO4, CsH2PO4 and their mixtures with $\mathrm{N}$-heterocycles
}

Aili, David; Gao, Ying; Han, Junyoung; Li, Qingfeng

Published in:

Solid State lonics

Link to article, DOI:

10.1016/j.ssi.2017.03.012

Publication date:

2017

Document Version

Peer reviewed version

Link back to DTU Orbit

Citation (APA):

Aili, D., Gao, Y., Han, J., \& Li, Q. (2017). Acid-base chemistry and proton conductivity of CsHSO , CsH PO and their mixtures with $\mathrm{N}$-heterocycles . Solid State lonics, 306, 13-19. https://doi.org/10.1016/j.ssi.2017.03.012

\section{General rights}

Copyright and moral rights for the publications made accessible in the public portal are retained by the authors and/or other copyright owners and it is a condition of accessing publications that users recognise and abide by the legal requirements associated with these rights.

- Users may download and print one copy of any publication from the public portal for the purpose of private study or research.

- You may not further distribute the material or use it for any profit-making activity or commercial gain

- You may freely distribute the URL identifying the publication in the public portal

If you believe that this document breaches copyright please contact us providing details, and we will remove access to the work immediately and investigate your claim. 


\title{
Acid-base chemistry and proton conductivity of $\mathrm{CsHSO}_{4}$,
}

\section{$\mathrm{CsH}_{2} \mathrm{PO}_{4}$ and their mixtures with $N$-heterocycles}

\author{
David Aili*, Ying Gao, Junyoung Han and Qingfeng Li \\ Department of Energy Conversion and Storage, Technical University of Denmark, Kemitorvet 207, \\ DK-2800 Kgs. Lyngby, Denmark, ${ }^{*}$ Corresponding author (E-mail: larda@dtu.dk)
}

\begin{abstract}
Caesium hydrogen sulfate $\left(\mathrm{CsHSO}_{4}\right)$ and caesium dihydrogen phosphate $\left(\mathrm{CsH}_{2} \mathrm{PO}_{4}\right)$ are solid acids that undergo superprotonic phase-transitions at about 140 and $230{ }^{\circ} \mathrm{C}$, respectively. As a result, the proton conductivity is increased by several orders of magnitude. However, the practical operational temperature range is narrow due to decomposition of the highconductivity phases. For $\mathrm{CsHSO}_{4}$, it is known that this window can be extended to lower temperatures by addition of carefully selected $N$-heterocycles. The present work investigates if the same approach can be used to extend the practical operating temperature of $\mathrm{CsH}_{2} \mathrm{PO}_{4}$ as well. Binary mixtures of $\mathrm{CsH}_{2} \mathrm{PO}_{4}$ with 1,2,4-triazole, benzimidazole or imidazole were prepared by means of mechanochemical synthesis. Mixtures based on $\mathrm{CsHSO}_{4}$ were prepared as a basis for a comparative discussion. It was found that $\mathrm{CsHSO}_{4}$ formed organic-inorganic salts, while $\mathrm{CsH}_{2} \mathrm{PO}_{4}$ formed heterogeneous mixtures with the $N$-heterocycles due to its weaker acidity. At a $N$-heterocycle content of $30 \mathrm{~mol} \%$, enhanced proton conductivity was observed for both solid acids at temperatures below the supertprotonic phase transitions.
\end{abstract}

Keywords: solid acid, caesium dihydrogen phosphate, composite, electrolyte, conductivity 


\section{Introduction}

The solid acid proton conductors based on tetrahedral oxyanions comprise a family of materials that has attracted considerable attention for their potential uses as proton conducting electrolytes in the intermediate temperature range from 100 to $300{ }^{\circ} \mathrm{C}$ [1-4]. Caesium dihydrogen phosphate $\left(\mathrm{CsH}_{2} \mathrm{PO}_{4}, \mathrm{CHP}\right)$, the mono caesium salt of phosphoric acid $\left(\mathrm{H}_{3} \mathrm{PO}_{4}\right)$, is among the most thoroughly studied solid acids, showing a superprotonic phase-transition at about $230{ }^{\circ} \mathrm{C}$ [5]. Above this threshold temperature a dynamic disordered hydrogen bond network is developed, resulting in an increase in the proton conductivity by several orders of magnitude. For example, when the temperature is increased from 223 to $233{ }^{\circ} \mathrm{C}$ the proton conductivity of CHP increases from $8.5 \times 10^{-6}$ to $1.8 \times 10^{-2} \mathrm{~S} \mathrm{~cm}^{-1}$ [3]. Fuel cells based on CHP thin films as electrolyte show power densities as high as $400 \mathrm{~mW} \mathrm{~cm}^{-2}$ at $240{ }^{\circ} \mathrm{C}$ [6]. However, at temperatures above $230{ }^{\circ} \mathrm{C}$ the $\mathrm{CHP}$ gradually dehydrates to $\mathrm{Cs}_{2} \mathrm{H}_{2} \mathrm{P}_{2} \mathrm{O}_{7}$ and further to $\mathrm{CsPO}_{3}$ [7]. Active humidification prevents the dehydration and stable fuel cell operation can be achieved at $235-243{ }^{\circ} \mathrm{C}$ [8]. In this connection, heterogeneous doping with alumina [9] or zirconia [10] have been found to suppress the dehydration and to stabilize the high conductivity phase. Similarly, at temperatures below the superprotonic phase transition the conductivity depends on the amount of water in the structure and particularly on strongly bound surfacewater [11]. To broaden the operational temperature window to lower temperatures, incorporation of caesium hydrogen sulfate $\left(\mathrm{CsHSO}_{4}, \mathrm{CHS}\right)$ [12-14] or finely dispersed $\mathrm{SiO}_{2}$ $[15,16], \mathrm{SrZrO}_{3}[17], \mathrm{H}_{3} \mathrm{PW}_{12} \mathrm{O}_{40}[18], \mathrm{NdPO}_{4}$ [19] or guanine [20] within the structure have proven successful.

CHS, the mono-caesium salt of sulfuric acid $\left(\mathrm{H}_{2} \mathrm{SO}_{4}\right)$, shows a similar superprotonic phase transition as $\mathrm{CHP}$ but at a considerably lower temperature of $140{ }^{\circ} \mathrm{C}$ [21]. In terms of stability, dehydration at temperatures above the superprotonic phase transition temperature is of critical concern for CHS as well [22]. The proton conductivity of CHS at temperatures below 
the superprotonic phase transition is typically in the $10^{-7}-10^{-6} \mathrm{~S} \mathrm{~cm}^{-1}$ range at $100-130{ }^{\circ} \mathrm{C}$ [21]. Several approaches to increase the proton conductivity of CHS in this temperature range have been reported throughout the years, focusing on the development of binary inorganic systems with $\mathrm{SiO}_{2}$ [23-25], $\mathrm{P}_{2} \mathrm{O}_{5}-\mathrm{SiO}_{2}$ [26], $\mathrm{TiO}_{2}$ [27], $\mathrm{H}_{3} \mathrm{PW}_{12} \mathrm{O}_{40}$ [28] or $\mathrm{CsH}_{2} \mathrm{PO}_{4}$ [12-14]. Recently, binary mixtures composed of $\mathrm{CHS}$ and organic $\mathrm{N}$-heterocycles were prepared by mechanochemical synthesis and thoroughly characterized [29, 30]. For the binary compounds of CHS containing $20 \mathrm{~mol} \%$ 1,2,4-triazole (Tz) or imidazole ( $\mathrm{Im})$ the conductivity reached as high as $10^{-3} \mathrm{~S} \mathrm{~cm}^{-1}$ at $80{ }^{\circ} \mathrm{C}$, which is about 3-4 orders of magnitude higher than that of the pure compounds. For the binary system with benzimidazole (BIm) the effect was considerably less pronounced. It was proposed that the acid-base interactions between the acidic CHS and basic $N$-heterocycles promote the disordering of the sulfate groups leading to enhanced proton mobility in the lower temperature regime [29, 30]. Similarly, addition of a small amount (up to $12 \mathrm{~mol} \%$ ) $\mathrm{Im}$ to $\mathrm{H}_{2} \mathrm{SO}_{4}$ has been found to promote the proton dissociation and generation of proton defects, ultimately leading to enhanced ion conductivity [31]. This is apparently different from phosphoric acid [32, 33], where water seems to be the only Brønsted base that can increase the concentration of ionic charge carriers as well as promote the proton mobility [34].

The proton conductivity of nominally dry phosphoric acid is remarkably high due its unique hydrogen-bond network structure, through which protons diffuse almost entirely by the Grotthuss-type mechanism at high phosphoric acid concentrations [35]. In combination with its low vapor pressure, it is therefore the most promising dopant used for high temperature polymer electrolyte membrane fuel cells based on $N$-heteroaromatic polymers [36, 37]. However, the strong adsorption of phosphoric acid on the platinum electrocatalysts at cathodic potentials results in poor performance at low currents. As discussed by Kreuer [34], replacing 
phosphoric acid with $\mathrm{CHP}$ as the proton conducting electrolyte could be one way to enhance the kinetics for the oxygen reduction reaction.

The present work focuses on the chemical and electrochemical characteristics of binary mixtures of CHP and organic $N$-heterocycles as a model system. A set of binary mixtures composed of CHS and the $\mathrm{N}$-heterocycles are prepared for comparison and the results are discussed in light of fundamental acid base chemistry.

\section{Experimental}

\subsection{Materials}

$\mathrm{CsH}_{2} \mathrm{PO}_{4}$ was prepared from a mixture of $\mathrm{Cs}_{2} \mathrm{CO}_{3}$ (Aldrich, 99\%) and aqueous $\mathrm{H}_{3} \mathrm{PO}_{4}$ (Aldrich, $85 \%$ ) with a slight over-stoichiometry of the acid. Polycrystalline $\mathrm{CsH}_{2} \mathrm{PO}_{4}$ was subsequently precipitated in methanol at room temperature. The precipitate was then filtered off and extensively washed with methanol and finally dried at $80{ }^{\circ} \mathrm{C}$ overnight.

$\mathrm{CsHSO}_{4}$ was prepared from an equimolar mixture of $\mathrm{Cs}_{2} \mathrm{SO}_{4}$ (Aldrich, 99\%) and $\mathrm{H}_{2} \mathrm{SO}_{4}$ (98\%, Aldrich) in aqueous solution. $\mathrm{CsHSO}_{4}$ was precipitated in methanol, isolated by filtration and extensively washed with methanol and dried for one week at $60{ }^{\circ} \mathrm{C}$.

The inorganic-organic binary compounds were synthesized by blending the $\mathrm{CsH}_{2} \mathrm{PO}_{4}$ or $\mathrm{CsHSO}_{4}$ with the $N$-heterocycles (1,2,4-triazole, benzimidazole and imidazole, SigmaAldrich) at different ratios, followed by solid-state ball milling at $700 \mathrm{rpm}$ for $4 \mathrm{~h}$, using a ball mill with an agate pot (Fritsch, $45 \mathrm{~mL}$ ) and 10 agate balls made of tungsten carbide (10 $\mathrm{mm}$ in diameter). The obtained materials were stored under dry inert atmosphere in a glove-box until further use. 


\subsection{Characterization}

Thermogravimetric analysis (TGA) and differential thermal analysis (DTA) were performed on a Netzsch STA 409 PC under air atmosphere at $10{ }^{\circ} \mathrm{C} \mathrm{min}^{-1}$. X-ray diffraction (XRD) was carried out using a Rigaku MiniFlex 600 equipped with a Cu K $\mathrm{X}_{\alpha}$-ray source $(\lambda=1.5418 \AA)$ in the range from $3^{\circ}$ to $100^{\circ} 2 \theta$. The Fourier transform infrared (FT-IR) spectra were recorded on a Perkin Elmer Spectrum Two in attenuated total reflectance (ATR) mode, using a Golden Gate high temperature heated diamond ATR top plate from Specac.

The proton conductivity was measured by electrochemical impedance spectroscopy over a frequency range of $1-10^{6} \mathrm{~Hz}$ using a Princeton Versastat 4 potentiostat equipped with Versastudio software. For electrochemical characterizations, the powders were pressed into disk-shaped tablets of $13 \mathrm{~mm}$ diameter of varying thicknesses (around $0.5 \mathrm{~mm}$ ). This was done by uniaxial pressing at $2000 \mathrm{~kg} \mathrm{~cm}^{-2}$ for 2 minutes at room temperature. In order to improve the contact between the pellet and the electrodes, a thin layer of silver paste (Loctite ${ }^{\circledR} 3863$, Henkel Co.) was painted on both sides of electrolyte tablets. For the humidity control, a mixture of air and water was used as the purging gas. Water was fed to an evaporator using a Shimadzu Prominence LC-20AD water pump and the steam was converged with the air-flow, decompressed from 7 bar and controlled by a Brooks Instrument 0254 mass flow meter. At temperatures below $100{ }^{\circ} \mathrm{C}$ the measurements were carried out under un-humidified air. Unless otherwise noted, the partial pressure of steam was 0.4 atm.

\section{Results and discussion}

Binary materials based on CHP or CHS and a set of $N$-heterocycles were prepared by mechanochemical synthesis, according to methodology previously described in the literature $[18,29]$. The fundamental physicochemical properties of the $N$-heterocycles are listed in Table 1 in the order of increasing basicity in water. 
Table $1 \mathrm{~N}$-heterocycles used for the screening and their corresponding physical properties [38].

\begin{tabular}{lllll}
\hline $\begin{array}{l}N \text {-heterocycle } \\
\text { (abbreviation) }\end{array}$ & Structure & Melting point $/{ }^{\circ} \mathrm{C}$ & Boiling point $/{ }^{\circ} \mathrm{C}$ & $\mathrm{p} K_{\mathrm{aH}}{ }^{\mathrm{a}}$ \\
\hline 1,2,4-triazole $(\mathrm{Tz})$ & & 260 & 2.4 \\
Benzimidazole (BIm) & & 360 & 5.6 \\
\hline Imidazole $(\mathrm{Im})$ & & 256 & 6.9 \\
\hline
\end{tabular}

${ }^{\mathrm{a}} \mathrm{In} \mathrm{H}_{2} \mathrm{O}$

The X-ray diffractograms in the range from $2 \theta=20-40^{\circ}$ of the binary mixtures of CHP or CHS containing $30 \mathrm{~mol} \%, \mathrm{Tz}, \mathrm{Im}$ or BIm are shown in Figure 1. The XRD patterns of the binary compounds based on CHS (Figure 1a-c) were apparently different from that of the individual components indicating the formation of ionic compound with a different crystalline structure than the starting materials $[29,30]$. Particularly, the main CHS peak at $2 \theta=25.1^{\circ}$ was found to shift to lower angles as previously reported [30]. In contrast, the XRD patterns of the binary compounds based on CHP (Figure 1d-f) were practically identical with that of CHP. The diffraction peaks originating from the $N$-heterocycles were very weak, indicating formation of an amorphous phase of the $N$-heterocycles within the crystalline CHP framework. However, as also observed for the binary compounds based on CHS, the CHP signals were shifted to lower angles in the binary compounds compared to the pure CHP. For example, the main peak of the monoclinic phase at $2 \theta=23.8^{\circ}$ for pure $\mathrm{CHP}$ [18] was shifted to about $2 \theta=23.5^{\circ}$ for the binary 
compounds with the $\mathrm{N}$-heterocycles, likely due to interactions with the amorphous $\mathrm{N}$ heterocycle phase.
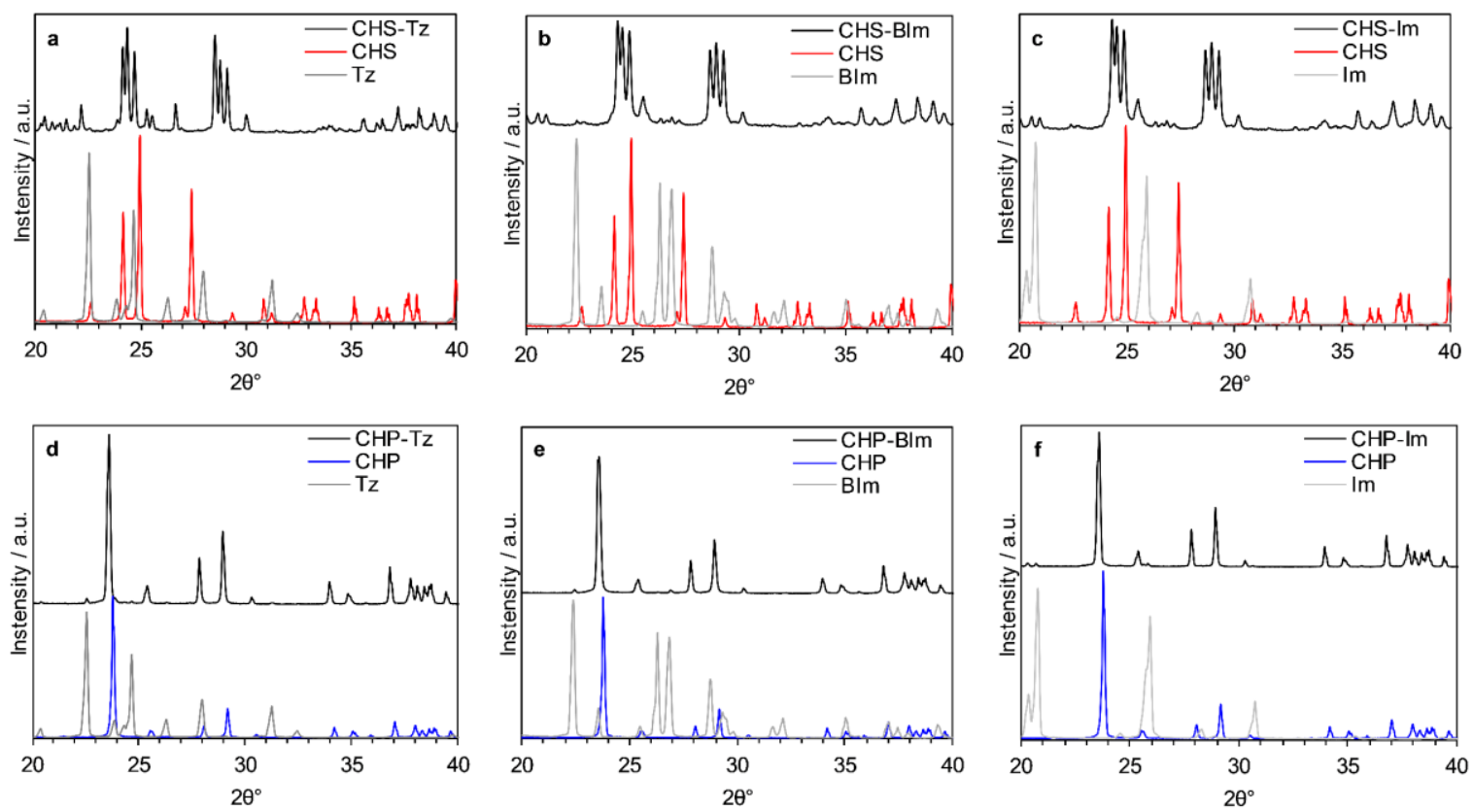

Figure 1 XRD of the binary compounds based on CHS (a-c) and CHP (d-f) containing 30 $\mathrm{mol} \% \mathrm{Tz}, \mathrm{BIm}$ or $\mathrm{Im}$.

The FT-IR spectra of the binary mixtures of CHP or CHS containing $30 \mathrm{~mol} \%$, Tz, Im or BIm are shown in Figure 2. The FT-IR spectra of pure CHS and CHP are shown for comparison, whose main spectral features have been assigned and discussed in more details [39-41]. The main absorption bands of the corresponding $N$-heterocycles are indicated by vertical dotted lines. On one hand, the FT-IR spectra of the binary mixtures of CHS showed signals that were not present in the spectra of the individual constituents (marked by + in Figure 2), indicating complete formation of homogenous inorganic-organic salts. For example, the new strong characteristic absorption band at about $1200 \mathrm{~cm}^{-1}$ present in all binary mixtures based on CHS corresponds to stretching modes of ionic sulfonates [40]. The strong $\mathrm{SO}_{4}$ absorption band at $570 \mathrm{~cm}^{-1}$ in pure CHS [40] was shifted to lower frequencies $\left(580 \mathrm{~cm}^{-1}\right)$ in the binary compounds 
further indicating altered chemical environment of the sulfonate. Furthermore, the absorption bands at 1577,1620 and $1586 \mathrm{~cm}^{-1}$ in spectra of the binary mixtures of CHS and Tz, BIm and Im, respectively, is indicative for the interaction between the two components $[29,30]$. On the other hand, the spectra of the binary mixtures based on CHP showed no significantly changed spectral features compared with the individual component. However, new weak absorption bands at 504 and $525 \mathrm{~cm}^{-1}$ appeared indicating changed chemical environment of the phosphate anions [20]. 

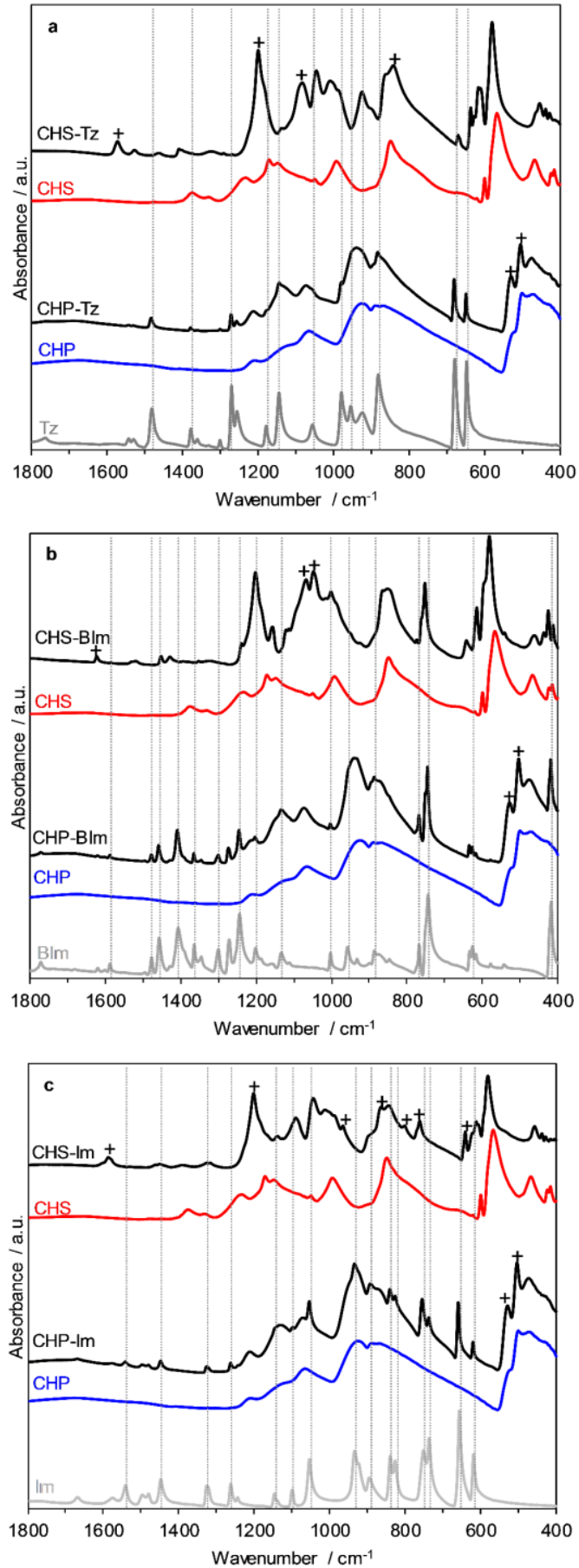

Figure 2 FT-IR spectra of the binary compounds (black lines) and of the corresponding individual components. The major absorption bands of the $N$-heterocycles are indicated by vertical lines. 
Thermogravimetric analysis (TGA) in combination with differential thermal analysis (DTA) was carried out in order to obtain more information about the thermal behavior of the binary mixtures. The TGA and DTA data for the binary mixtures based on CHS and CHP are shown in Figure 3a-c and 3d-f, respectively, plotted together with the data for the corresponding individual components. The endothermic peak temperatures and the onset temperatures of the major mass loss steps are summarized in Table 2.

The dehydration of CHP occurred in two steps, with a first onset close to the superprotonic phase transition $\left(227^{\circ} \mathrm{C}\right)$. Tz, BIm and Im showed the first endothermic peaks at 119,170 and $88{ }^{\circ} \mathrm{C}$, respectively, in good agreements with the melting temperatures (see Table 1). Furthermore, endothermic peaks were recorded at 208,284 and $220^{\circ} \mathrm{C}$, respectively, likely corresponding to the boiling. However, the major onset of weight loss for $\mathrm{Tz}, \mathrm{BIm}$ and Im was about 137,205 and $140{ }^{\circ} \mathrm{C}$, indicating that the vapor pressure at temperatures well below the boiling temperatures is sufficiently high to result in a significant evaporation rate. The endothermic peaks of the binary mixtures based on CHP were in agreement with the peaks of the individual components, further supporting the XRD and FT-IR data. 

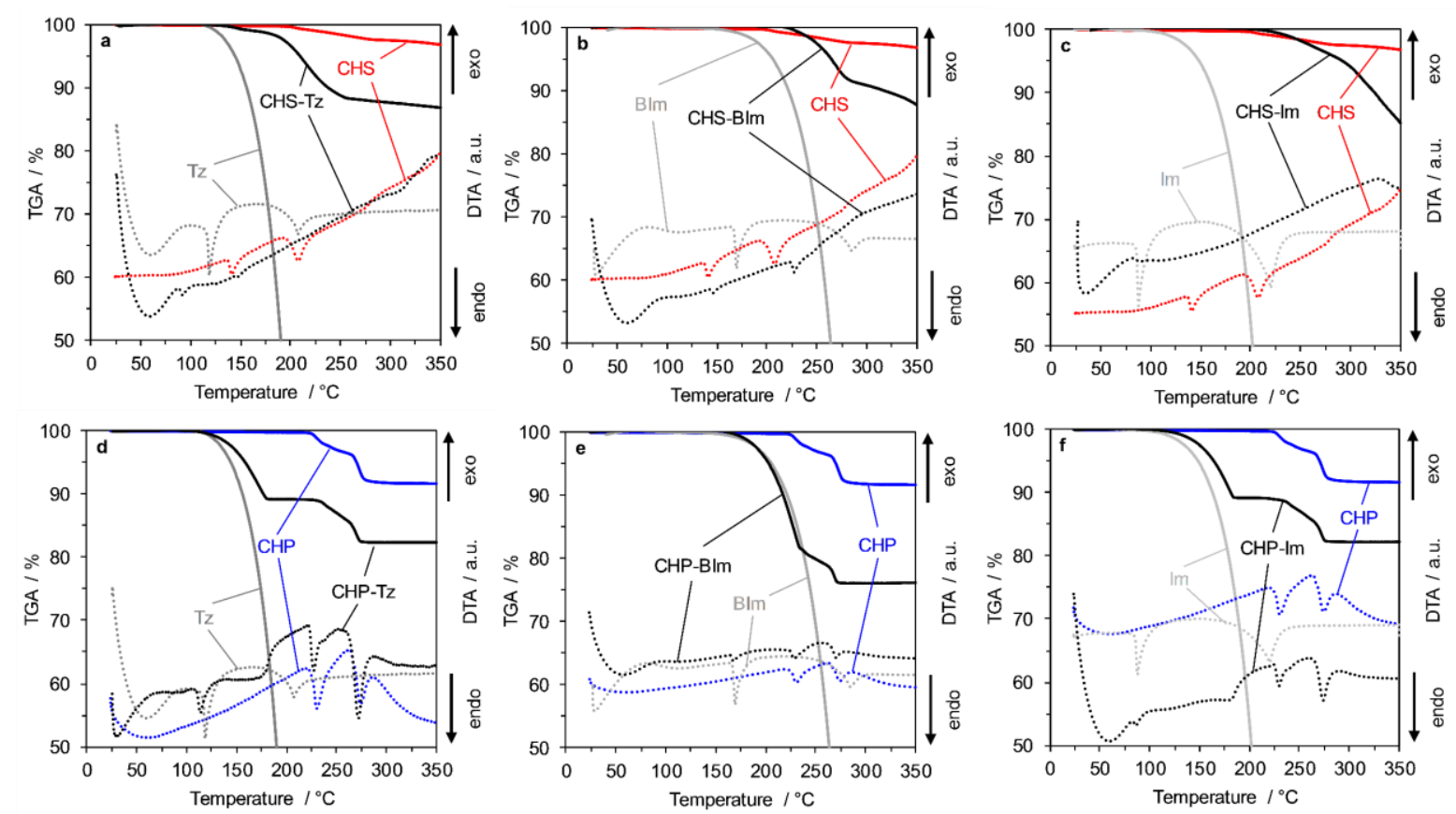

Figure 3 Thermogravimetric curves (solid lines) and differential thermal analysis data (dotted lines) for the CHS (a-c) and CHP (d-f) binary compounds containing $30 \mathrm{~mol} \% \mathrm{Tz}$,

BIm and Im. 
Table 2 Endothermic peaks and major onsets of weight loss temperatures of CHP, CHS, Tz, Im and BIm and of the CHP and CHS binary compounds containing $30 \mathrm{~mol} \% \mathrm{Tz}, \mathrm{Im}$ and $\mathrm{BIm}$. Data extracted from TGA/DTA measurements at $10{ }^{\circ} \mathrm{C} \min ^{-1}$.

\begin{tabular}{lll}
\hline Sample & Endothermic peaks $/{ }^{\circ} \mathrm{C}$ & Onsets of weight loss $/{ }^{\circ} \mathrm{C}$ \\
\hline CHS & 140,206 & 197,326 \\
CHP & 230,273 & 227,266 \\
Tz & 119,208 & 137 \\
BIm & 170,284 & 205 \\
Im & 88,220 & 140 \\
CHS-Tz & 91 & 146,190 \\
CHS-BIm & 145,228 & 232,333 \\
CHS-Im & - & 225,297 \\
CHP-Tz & $114,228,271$ & $150,234,263$ \\
CHP-BIm & $169,230,271$ & 201,262 \\
CHP-Im & $87,230,275$ & $144,234,269$ \\
\hline
\end{tabular}

In context of the acid-base chemistry, the results from the XRD, FT-IR and TGA/DTA studies in the present work confirm previously reported data for the mixtures based on CHS [29, 30]. The $\mathrm{p} K_{\mathrm{a}}$ corresponding to the dissociation of $\mathrm{HSO}_{4}{ }^{-}$is 2.0 (in water), which is similar to the $\mathrm{p} K_{\mathrm{a}}$ corresponding to the dissociation of $\mathrm{H}_{3} \mathrm{PO}_{4}$. Consider the varied $\mathrm{p} K_{\mathrm{aH}}$ values of 2.4 for $\mathrm{Tz}$, 5.6 for BIm and 6.9 for Im, CHS is sufficiently acidic to interact with Tz, BIm and Im, leading to formation of extensive hydrogen bonds or eventually inorganic-organic ionic salts by complete transfer of its proton, as shown in Figure 4 (left).

The $\mathrm{p} K_{\mathrm{a}}$ corresponding to the dissociation of $\mathrm{H}_{2} \mathrm{PO}_{4}{ }^{-}$, on the other hand, is around 7.2 in water. It indicates that CHP is about 5 orders of magnitude less acidic than CHS and thus 
not sufficiently acidic to protonate $\mathrm{Tz}, \mathrm{BIm}$ or Im to any significant extent. Heterogeneous mixtures were thus obtained when CHP was mixed with the $N$-hetercycles, as illustrated in Figure 4 (right).<smiles></smiles><smiles>[14CH3]OS(=O)(=O)[O-]</smiles><smiles>O=S(=O)([O-])O[CH-][n+]1cc[nH]c1</smiles><smiles></smiles><smiles>COP(=O)(O)O[C@H]1CNc2ccccc21</smiles><smiles></smiles>

Figure 4 Chemical structures of the binary $N$-heterocycle mixtures based on CHS (left) and CHP (right).

We can now have a closer look at the TGA/DTA data in Table 2. Strong acid-base interactions between CHS and Im (strongest), BIm (medium) and $\mathrm{Tz}$ (weakest) result in formation of inorganic-organic salts and therefore stabilize the volatile base molecules by electrostatic interactions. As a result, the onset temperatures are found to increase by $85{ }^{\circ} \mathrm{C}$ for CHS-Im, 27 ${ }^{\circ} \mathrm{C}$ for CHS-BIm, and $9{ }^{\circ} \mathrm{C}$ for $\mathrm{CHS}$-Tz compared to the individual $\mathrm{N}$-heterocycle. For the CHP mixtures, however, the mismatched acidity relative to the $N$-heterocycles leads to a low degree of ionization and the thermogravimetric behavior of the volatile bases thus remains unchanged in relation to their pristine forms. The binary systems based on CHP are therefore better understood as heterogeneous composite systems, rather than homogenous mixtures.

As shown in Figure 5, the ion conductivity of pure CHS and CHP was found to increase by several orders of magnitude at about 140 and $230{ }^{\circ} \mathrm{C}$, respectively, in good agreement with the data in the literature $[5,21]$. As described previously in the literature $[3,9]$, the ion 
conductivity of CHP and CHS showed thermal hysteresis during the heating-cooling loop. The binary mixtures of $\mathrm{CHS}$ and $\mathrm{Tz}$ or $\mathrm{Im}$ showed significantly enhanced conductivity at temperatures below the superprotonic phase transition of pure CHS, confirming the results reported by $\mathrm{Oh}$ et al. [30]. For example, the ion conductivity at $100{ }^{\circ} \mathrm{C}$ of the binary mixtures of CHS and Tz or Im was about $1.5 \mathrm{mS} \mathrm{cm}^{-1}$, as compared with about $6 \times 10^{-4} \mathrm{mS} \mathrm{cm}^{-1}$ for pure CHS.

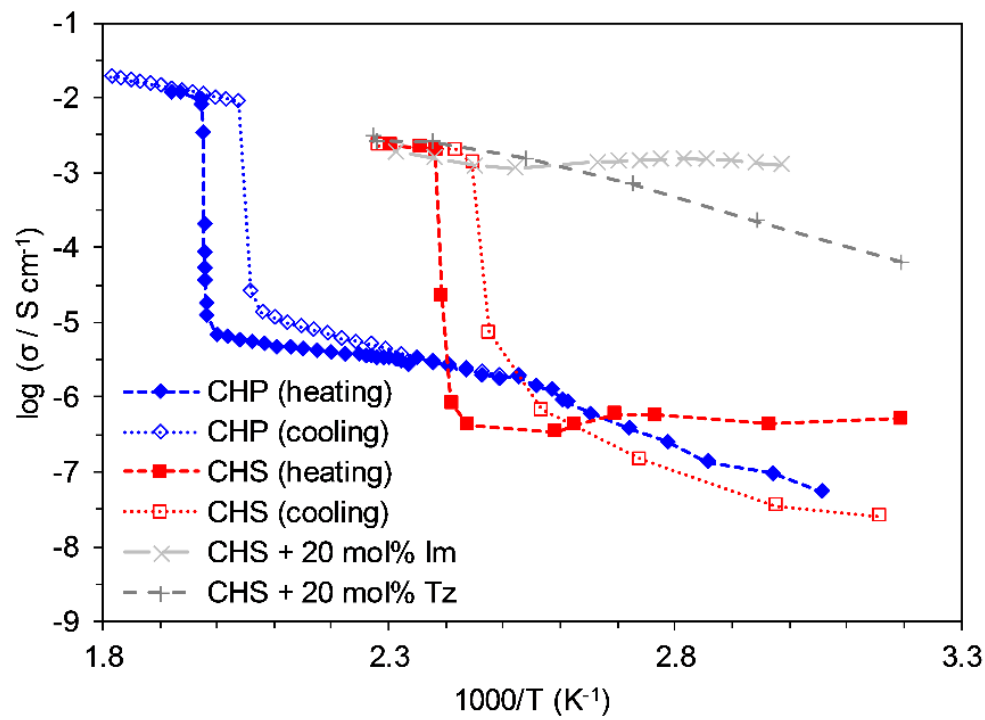

Figure 5 Conductivity of CHS doped with 20 mol\% imidazole or 1,2,4-triazole measured without humidification. The conductivity of pure CHS and CHP is shown for comparison for the first heating (solid) and cooling (open) cycles.

The ion conductivity of the binary compounds composed of CHP and $30 \mathrm{~mol} \% \mathrm{Tz}, \mathrm{BIm}$ or Im was recorded at temperature ranging from $50-250{ }^{\circ} \mathrm{C}$, as shown in Figure $6 \mathrm{a}$. The conductivity of the binary CHP-BIm mixture was marginally higher than that of pure CHP at temperatures below $240{ }^{\circ} \mathrm{C}$, likely due to the high melting temperature of BIm in combination with its relatively high molecular weight [30]. In the lower temperature range, the conductivity of the binary mixtures with $\mathrm{Tz}$ and $\mathrm{Im}$ gradually increased with increasing temperature and reached 
a plateau at 119 and $90{ }^{\circ} \mathrm{C}$, respectively, i.e. at the corresponding melting temperatures of the secondary components. The conductivity remained stable at about $0.2-0.8 \mathrm{mS} \mathrm{cm}^{-1}$ up to $174-$ $190{ }^{\circ} \mathrm{C}$, beyond which it started to decline due to evaporation as supported by the TGA/DTA data and the temperature dependent FT-IR spectra (Figure S1). It can thus be expected that the chemical composition as well as the conductivity of the binary CHP-Tz/Im mixtures strongly depend on the thermal history of the sample.

To assess the stability of the composite electrolytes, the conductivity of the binary mixtures with $\mathrm{Tz}$ and $\mathrm{Im}$ was recorded at $130^{\circ} \mathrm{C}$ during more than $12 \mathrm{~h}$ as shown in Figure $6 \mathrm{~b}$. The conductivity of the binary composite with Im was initially slightly higher than for the corresponding sample measured during the heating scan, likely due to batch-to-batch variations. The conductivity of the binary composites of CHP containing $30 \mathrm{~mol} \% \mathrm{Tz}$ or Im was initially 0.7 and $1.1 \mathrm{mS} \mathrm{cm}^{-1}$, respectively. After $12 \mathrm{~h}$ it had decreased to 0.3 and $0.5 \mathrm{mS}$ $\mathrm{cm}^{-1}$, respectively, likely due to evaporation of the $N$-heterocycles. 

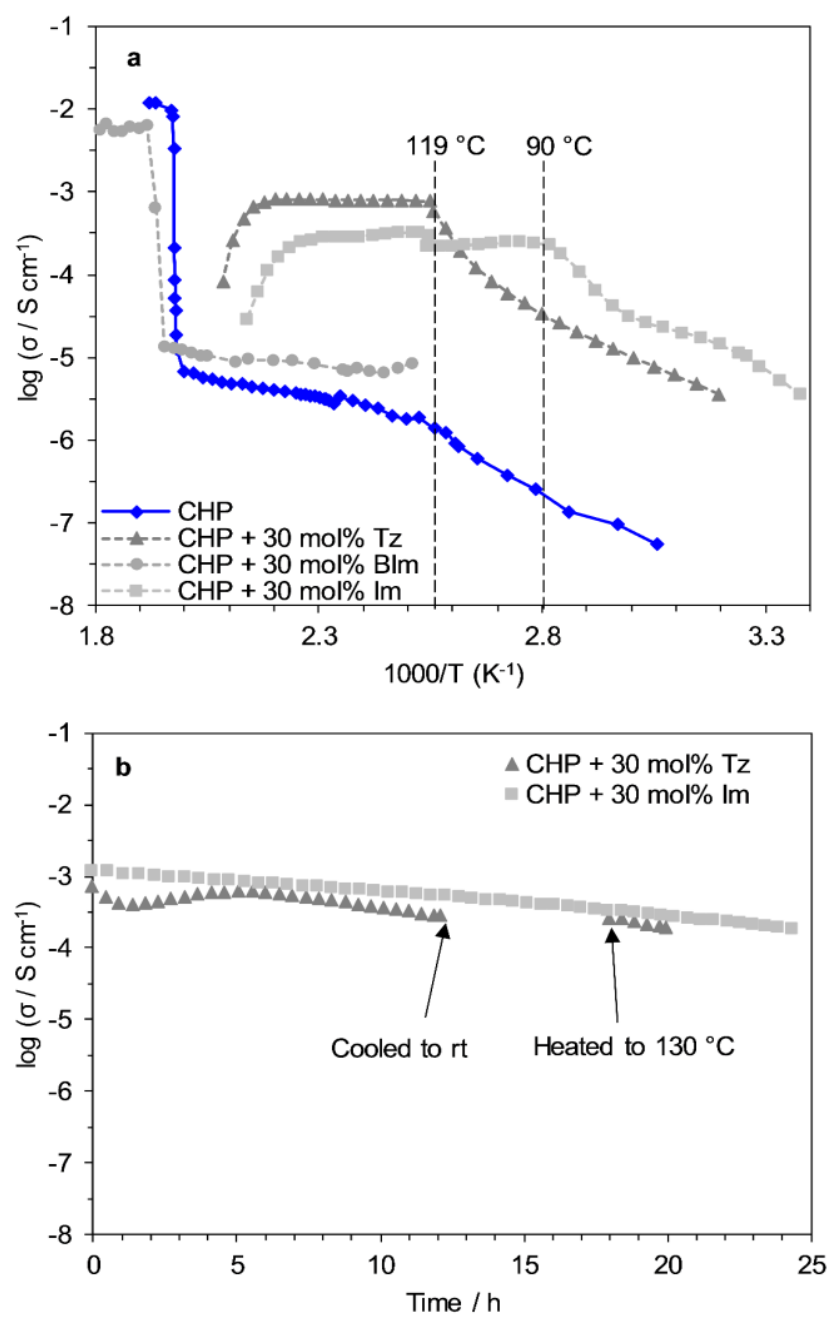

Figure 6 Conductivity of the binary compounds of CHP and $30 \mathrm{~mol} \% \mathrm{Tz}, \mathrm{BIm}$ or Im as functions of temperature (a) and of the binary compounds of CHP with $30 \mathrm{~mol} \% \mathrm{Tz}$ or Im at $130{ }^{\circ} \mathrm{C}$ as functions of time (b).

The binary mixture of CHP with Tz was chosen for further studies with respect to composition. Binary mixtures of CHP and 10, 30 and $50 \mathrm{~mol} \% \mathrm{Tz}$ were prepared and their conductivity is plotted as functions of temperature in Figure 7. At temperatures below the melting point of Tz, the conductivity increased gradually with increasing temperature. At $90{ }^{\circ} \mathrm{C}$ the conductivity of the CHP mixture containing $30 \mathrm{~mol} \% \mathrm{Tz}$ was $4.5 \times 10^{-5} \mathrm{~S} \mathrm{~cm}^{-1}$, which can be compared with $8 \times 10^{-6} \mathrm{~S} \mathrm{~cm}^{-1}$ for pure $\mathrm{Tz}$ [42]. Above the melting temperature of $\mathrm{Tz}$, the conductivity of the binary mixtures of CHP containing 30 and $50 \mathrm{~mol} \% \mathrm{Tz}$ was similar and reached around $1 \mathrm{mS}$ 
$\mathrm{cm}^{-1}$ at $120^{\circ} \mathrm{C}$. For comparison, the ion conductivity of pure $\mathrm{CHP}$ and $\mathrm{Tz}$ at $120{ }^{\circ} \mathrm{C}$ was $1.7 \times$ $10^{-6}$ and $1.5 \times 10^{-3} \mathrm{~S} \mathrm{~cm}^{-1}$, respectively. Even at a low Tz content, $10 \mathrm{~mol} \%$, the ion conductivity was significantly enhanced at $120-130{ }^{\circ} \mathrm{C}$ and reached $6 \times 10^{-5} \mathrm{~S} \mathrm{~cm}^{-1}$. For comparison, the conductivity of molten Tz increased from $2.0 \times 10^{-3}$ to $2.4 \times 10^{-3} \mathrm{~S} \mathrm{~cm}^{-1}$ when the temperature was increased from 130 to $160{ }^{\circ} \mathrm{C}$.

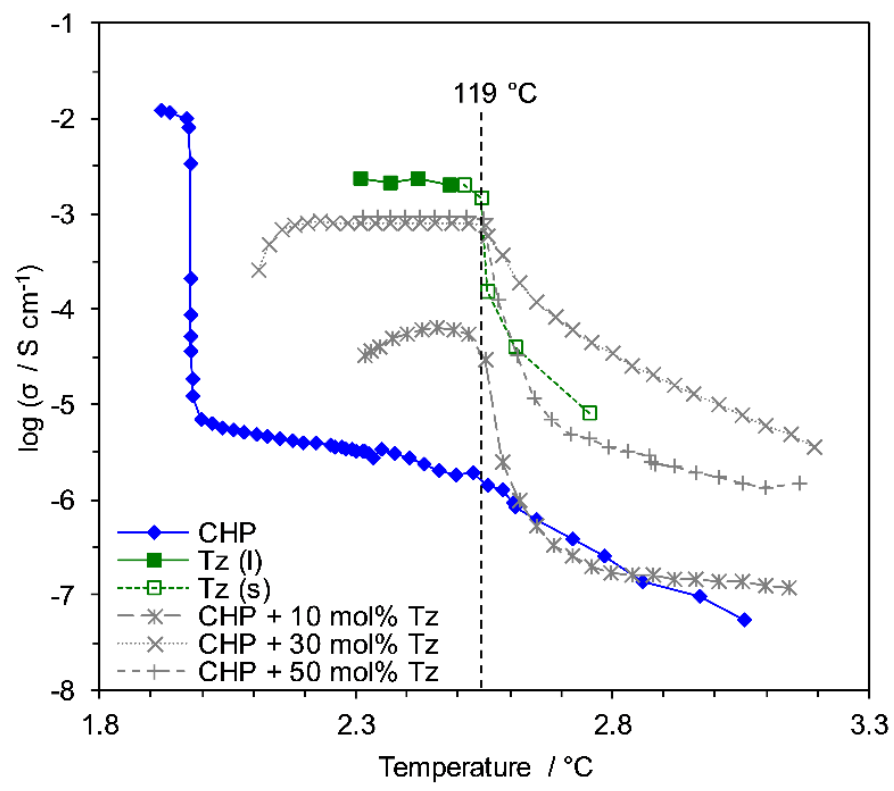

Figure 7 Conductivity of CHP mixtures containing 10, 30 and $50 \mathrm{~mol} \% \mathrm{Tz}$. The conductivity of $\mathrm{Tz}$ in liquid (1) [42] and solid (s) state is shown for comparison.

As discussed above, the binary systems based on CHP and the $N$-heterocycles are best described as heterogeneous composite systems composed of a $N$-heterocycle phase dispersed in a structural porous matrix of CHP. In this connection, the physicochemical properties of the composite electrolyte largely depend on the structure of the composite and the interphases between the components [43]. In confined spaces, the physicochemical properties and ion conductivity behavior of $N$-heterocycles such as Im [44] or Tz [45] can be strongly modulated. In this work, it is obvious that the $N$-heterocycles dispersed in the solid acid matrix phase 
provide an environment that show enhanced ion conductivity at temperatures well-below the superprotonic phase transition of CHP. This is likely due to weak hydrogen-bond interactions between CHP and the $N$-heterocycles, promoting the proton dissociation and thus the generation of proton defects, which mechanistically is an underlying process in the conduction of protons $[46,47]$.

\section{Conclusions}

Binary mixtures of $\mathrm{CsHSO}_{4}$ and $\mathrm{CsH}_{2} \mathrm{PO}_{4}$ with 1,2,4-triazole, benzimidazole or imidazole were prepared by means of mechanochemical synthesis. XRD, TGA/DTA and FT-IR results show that $\mathrm{CsHSO}_{4}$ formed homogenous mixtures i.e. organic-inorganic salts with the $\mathrm{N}$ heterocycles. $\mathrm{CsH}_{2} \mathrm{PO}_{4}$ was found to be insufficiently acidic to protonate the $N$-heterocycles to any significant extent. As a result of the acid-base interaction and the developed electrostatic interactions, the $\mathrm{CsHSO}_{4}$ mixtures with $N$-heterocycles show improved thermal stabilities with respect to the volatile basic components. Significant enhancement of proton conductivity was achieved in the temperature range lower than the supertprotonic phase transition. On the other hand, no acid-base chemistry was identified for the $\mathrm{CsH}_{2} \mathrm{PO}_{4}$ mixtures where the $\mathrm{N}$ heterocycles possess similar volatility as in their pristine form. Those binary systems are therefore best described as composites rather than homogenous mixtures. The proton conductivity of the binary mixtures based on $\mathrm{CsH}_{2} \mathrm{PO}_{4}$ was considerably enhanced at temperatures below the supertprotonic phase transition of $\mathrm{CsH}_{2} \mathrm{PO}_{4}$ and below the evaporation temperatures of the $N$-heterocycle additives. This could be due to to promotion of proton dissociation by the basic $N$-heterocycles or due to altered conductivity behavior of the confined $\mathrm{N}$-heterocycles within the porous CHP matrix. 


\section{Acknowledgments}

This work was financially supported by the Danish Council for Strategic Research (4M Centre).

\section{References}

[1] T. Norby, Solid-state protonic conductors: principles, properties, progress and prospects, Solid State Ionics 125 (1999) 1-11.

[2] S.M. Haile, D.A. Boysen, C.R.I. Chisholm, R.B. Merle, Solid acids as fuel cell electrolytes, Nature 410 (2001) 910-913.

[3] S.M. Haile, C.R.I. Chisholm, K. Sasaki, D.A. Boysen, T. Uda, Solid acid proton conductors: from laboratory curiosities to fuel cell electrolytes, Faraday Discuss. 134 (2007) 17-39.

[4] N. Mohammad, A.B. Mohamad, A.A.H. Kadhum, K.S. Loh, A review on synthesis and characterization of solid acid materials for fuel cell applications, J. Power Sources 322 (2016) 77-92.

[5] A.I. Baranov, B.V. Merinov, A.V. Tregubchenko, V.P. Khiznichenko, L.A. Shuvalov, N.M. Schagina, Fast proton transport in crystals with a dynamically disordered hydrogen bond network, Solid State Ionics 36 (1989) 279-282.

[6] T. Uda, S.M. Haile, Thin-membrane solid-acid fuel cell, Electrochem. Solid-State Lett. 8 (2005) A245-A246.

[7] Y.K. Taninouchi, T. Uda, Y. Awakura, A. Ikeda, S.M. Haile, Dehydration behavior of the superprotonic conductor $\mathrm{CsH}_{2} \mathrm{PO}_{4}$ at moderate temperatures: 230 to $260{ }^{\circ} \mathrm{C}, \mathrm{J}$. Mater. Chem. 17 (2007) 3182-3189.

[8] D.A. Boysen, T. Uda, C.R.I. Chisholm, S.M. Haile, High-performance solid acid fuel cells through humidity stabilization, Science 303 (2004) 68-70. 
[9] A.I. Baranov, V.V. Grebenev, A.N. Khodan, V.V. Dolbinina, E.P. Efremova, Optimization of superprotonic acid salts for fuel cell applications, Solid State Ionics 176 (2005) 2871-2874.

[10] A.H. Jensen, Q. Li, E. Christensen, N.J. Bjerrum, Intermediate temperature fuel cell using $\mathrm{CsH}_{2} \mathrm{PO}_{4} / \mathrm{ZrO}_{2}$-based composite electrolytes, J. Electrochem. Soc. 161 (2014) F72-F76.

[11] D.A. Boysen, S.M. Haile, H.J. Liu, R.A. Secco, High-temperature behavior of $\mathrm{CsH}_{2} \mathrm{PO}_{4}$ under both ambient and high pressure conditions, Chem. Mater. 15 (2003) 727-736.

[12] T. Sugahara, A. Hayashi, K. Tadanaga, M. Tatsumisago, Characterization of proton conducting $\mathrm{CsHSO}_{4}-\mathrm{CsH}_{2} \mathrm{PO}_{4}$ ionic glasses prepared by the melt-quenching method, Solid State Ionics 181 (2010) 190-192.

[13] H. Takahashi, Y. Suzuki, T. Sakuma, New phase transition in superprotonic phase of inorganic solid acid $\mathrm{Cs}_{2}\left(\mathrm{HSO}_{4}\right)\left(\mathrm{H}_{2} \mathrm{PO}_{4}\right)$, Solid State Ionics 285 (2016) 155-159.

[14] I.N. Bagryantseva, V.G. Ponomareva, Proton conductivity and phase composition of mixed salts in the systems $M \mathrm{H}_{2} \mathrm{PO}_{4}-\mathrm{CsHSO}_{4}(M=\mathrm{Cs}, \mathrm{K})$, Phys. Solid State 58 (2016) $1651-1658$.

[15] J. Otomo, N. Minagawa, C.-j. Wen, K. Eguchi, H. Takahashi, Protonic conduction of $\mathrm{CsH}_{2} \mathrm{PO}_{4}$ and its composite with silica in dry and humid atmospheres, Solid State Ionics 156 (2003) 357-369.

[16] V.G. Ponomareva, E.S. Shutova, High-temperature behavior of $\mathrm{CsH}_{2} \mathrm{PO} 4$ and $\mathrm{CsH}_{2} \mathrm{PO}_{4}-\mathrm{SiO}_{2}$ composites, Solid State Ionics 178 (2007) 729-734.

[17] G.V. Lavrova, E.S. Shutova, V.G. Ponomareva, L.A. Dunyushkina, Proton conductivity and interphase interaction in $\mathrm{CsH}_{2} \mathrm{PO}_{4}-\mathrm{SrZrO}_{3}$ composites, Russ. J. Electrochem. 49 (2013) 718-724. 
[18] S.-Y. Oh, E.K. Insani, V.H. Nguyen, G. Kawamura, H. Muto, M. Sakai, A. Matsuda, Mechanochemically synthesized $\mathrm{CsH}_{2} \mathrm{PO}_{4}-\mathrm{H}_{3} \mathrm{PW}_{12} \mathrm{O}_{40}$ composites as protonconducting electrolytes for fuel cell systems in a dry atmosphere, Sci. Technol. Adv. Mater. 12 (2011) 034402.

[19] T. Anfimova, A.H. Jensen, E. Christensen, J.O. Jensen, N.J. Bjerrum, Q. Li, $\mathrm{CsH}_{2} \mathrm{PO}_{4} / \mathrm{NdPO}_{4}$ composites as proton conducting electrolytes for intermediate temperature fuel cells, J. Electrochem. Soc. 162 (2015) F436-F441.

[20] S.-y. Oh, G. Kawamura, H. Muto, A. Matsuda, Mechanochemical synthesis of proton conductive composites derived from cesium dihydrogen phosphate and guanine, Solid State Ionics 225 (2012) 223-227.

[21] A.I. Baranov, L.A. Shuvalov, N.M. Shchagina, Superion conductivity and phase transitions in $\mathrm{CsHSO}_{4}$ and $\mathrm{CsHSeO}_{4}$ crystals, JETP Lett. 36 (1982) 459-462.

[22] R.B. Merle, C.R.I. Chisholm, D.A. Boysen, S.M. Haile, Instability of sulfate and selenate solid acids in fuel cell environments, Energy Fuels 17 (2003) 210-215.

[23] V.G. Ponomareva, N.F. Uvarov, G.V. Lavrova, E.F. Hairetdinov, Composite protonic solid electrolytes in the $\mathrm{CsHSO}_{4}-\mathrm{SiO}_{2}$ system, Solid State Ionics 90 (1996) 161-166.

[24] S.Q. Wang, J. Otomo, M. Ogura, C. Wen, H. Nagamoto, H. Takahashi, Preparation and characterization of proton-conducting $\mathrm{CsHSO}_{4}-\mathrm{SiO}_{2}$ nanocomposite electrolyte membranes, Solid State Ionics 176 (2005) 755-760.

[25] M. Saito, Y. Nozaki, H. Tokuno, N. Sakai, J. Kuwano, Proton conduction in $\mathrm{CsHSO}_{4}-$ mesoporous silica composite electrolytes, Solid State Ionics 180 (2009) 575-579.

[26] M. Tatsumisago, T. Tezuka, A. Hayashi, K. Tadanaga, Preparation of proton conductive composites with cesium hydrogen sulfate and phosphosilicate gel, Solid State Ionics 176 (2005) 2909-2912. 
[27] H. Muroyama, T. Matsui, R. Kikuchi, K. Eguchi, Composite effect on the structure and proton conductivity for $\mathrm{CsHSO}_{4}$ electrolytes at intermediate temperatures, J. Electrochem. Soc. 153 (2006) A1077-A1080.

[28] Y. Daiko, V.H. Nguyen, T. Yazawa, H. Muto, M. Sakai, A. Matsuda, Phase transition and proton conductivity of $\mathrm{CsHSO}_{4}-\mathrm{WPA}$ composites prepared by mechanical milling, Solid State Ionics 181 (2010) 183-186.

[29] S.-Y. Oh, T. Yoshida, G. Kawamura, H. Muto, A. Matsuda, Solid-state mechanochemical synthesis of $\mathrm{CsHSO}_{4}$ and 1,2,4-triazole inorganic-organic composite electrolytes for dry fuel cells, Electrochim. Acta 56 (2011) 2364-2371.

[30] S.-Y. Oh, G. Kawamura, H. Muto, A. Matsuda, Anhydrous protic conduction of mechanochemically synthesized $\mathrm{CsHSO}_{4}$-azole-derived composites, Electrochim. Acta 75 (2012) 11-19.

[31] K.-D. Kreuer, A. Fuchs, M. Ise, M. Spaeth, J. Maier, Imidazole and pyrazole-based proton conducting polymers and liquids, Electrochim. Acta 43 (1998) 1281-1288.

[32] A. Schechter, R.F. Savinell, Imidazole and 1-methyl imidazole in phosphoric acid doped polybenzimidazole, electrolyte for fuel cells, Solid State Ionics 147 (2002) 181187.

[33] L. Vilčiauskas, M.E. Tuckerman, J.P. Melchior, G. Bester, K.-D. Kreuer, First principles molecular dynamics study of proton dynamics and transport in phosphoric acid/imidazole (2:1) system, Solid State Ionics 252 (2013) 34-39.

[34] K.-D. Kreuer, Ion conducting membranes for fuel cells and other electrochemical devices, Chem. Mater. 26 (2014) 361-380.

[35] L. Vilčiauskas, M.E. Tuckerman, G. Bester, S.J. Paddison, K.-D. Kreuer, The mechanism of proton conduction in phosphoric acid, Nat. Chem. 4 (2012) 461-466. 
[36] Q. Li, J.O. Jensen, R.F. Savinell, N.J. Bjerrum, High temperature proton exchange membranes based on polybenzimidazoles for fuel cells, Prog. Polym. Sci. 34 (2009) 449-477.

[37] J.K. Kallitsis, M. Geormezi, S.G. Neophytides, Polymer electrolyte membranes for high-temperature fuel cells based on aromatic polyethers bearing pyridine units, Polym. Int. 58 (2009) 1226-1233.

[38] Q. Li, D. Aili, R.F. Savinell, J.O. Jensen, Acid-base chemistry and proton conductivity, in: Q. Li, D. Aili, H.A. Hjuler, J.O. Jensen (Eds.), High temperature polymer electrolyte membrane fuel cells: Approaches, status, and perspectives, Springer International Publishing, Cham, 2016, pp. 37-57.

[39] B. Marchon, A. Novak, Vibrational study of $\mathrm{CsH}_{2} \mathrm{PO}_{4}$ and $\mathrm{CsD}_{2} \mathrm{PO}_{4}$ single crystals, J. Chem. Phys. 78 (1983) 2105-2120.

[40] J. Baran, M.K. Marchewka, Vibrational investigation of phase transitions in $\mathrm{CsHSO}_{4}$ crystal, J. Mol. Struct. 614 (2002) 133-149.

[41] P. Colomban, M. Pham-Thi, A. Novak, Influence of thermal and mechanical treatment and of water on structural phase transitions in $\mathrm{CsHSO}_{4}$, Solid State Ionics 24 (1987) 193-203.

[42] S.W. Li, Z. Zhou, Y.L. Zhang, M.L. Liu, W. Li, 1H-1,2,4-triazole: An effective solvent for proton-conducting electrolytes, Chem. Mater. 17 (2005) 5884-5886.

[43] V. Ponomareva, G. Lavrova, Controlling the proton transport properties of solid acids via structural and microstructural modification, J. Solid State Electrochem. 15 (2011) 213-221.

[44] S. Bureekaew, S. Horike, M. Higuchi, M. Mizuno, T. Kawamura, D. Tanaka, N. Yanai, S. Kitagawa, One-dimensional imidazole aggregate in aluminium porous coordination polymers with high proton conductivity, Nat. Mater. 8 (2009) 831-836. 
[45] J.A. Hurd, R. Vaidhyanathan, V. Thangadurai, C.I. Ratcliffe, I.L. Moudrakovski, G.K.H. Shimizu, Anhydrous proton conduction at 150 degrees $\mathrm{C}$ in a crystalline metalorganic framework, Nat. Chem. 1 (2009) 705-710.

[46] T. Dippel, K.-D. Kreuer, J.C. Lassègues, D. Rodriguez, Proton conductivity in fused phosphoric acid; A ${ }^{1} \mathrm{H} /{ }^{31}$ P PFG-NMR and QNS study, Solid State Ionics 61 (1993) 4146.

[47] T. Dippel, N. Hainovsky, K.-D. Kreuer, W. Munch, J. Maier, Hydrogen bonding, lattice dynamics and fast protonic conductivity, Ferroelectrics 167 (1995) 59-66. 